\title{
Influence of the endometrium, protease inhibitors and freezing on antiviral activity of proteins secreted by pig conceptuses*
}

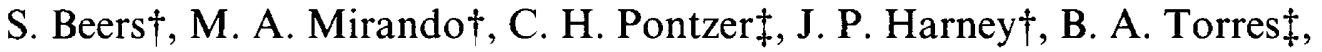 \\ H. M. Johnson $\ddagger$ and F. W. Bazer $\dagger$ \\ Departments of $\dagger$ Animal Science and $\ddagger$ Microbiology and Cell Science, University of Florida, \\ Gainesville, FL 32611, USA
}

\begin{abstract}
Summary. In Exp. 1, only medium from cultures containing conceptus tissue had antiviral activity $(P<0.05)$. Addition of Day-15 pregnant endometrium or Day-14 cyclic uterine flush proteins to cultures containing $200 \mathrm{mg}$ conceptus tissue decreased antiviral activity (conceptus $\times$ endometrial protein interaction, $P<0.06$ ). Effects of endometrium $(-54 \%)$ and uterine flush proteins $(-40 \%)$ on antiviral activity of conceptus cultures did not differ from each other $(P>0 \cdot 10)$. In Exp. 2, antiviral activity was only detected in cultures containing conceptus tissue $(P<0.06)$. The amount of antiviral activity in cultures of Day-15 conceptus tissue was not influenced differently $(P>0 \cdot 10)$ by culture in medium conditioned by endometrium from Day 10 or Day 12 of pregnancy. However, antiviral activity was undetectable in medium conditioned by endometrium from one of the Day-12 gilts. In Exp. 3, antiviral activity was present in medium from only 1 of 3 cultures from Day- 12 gilts when assayed unfrozen. Antiviral activity was lower $(P<0.01)$ in cultures of conceptuses from Day 12 than Day 14 of pregnancy; however, antiviral activity increased quadratically $(P<0.05)$ when cultures contained $0,0.01,0.1$ and $1.0 \mathrm{units} / \mathrm{ml}$ aprotinin, respectively. Freezing and thawing culture medium did not reduce $(P>0 \cdot 10)$ antiviral activity compared to medium assayed unfrozen (1438 vs 1354 units/ml, respectively). These results suggest a regulatory influence of the endometrium on secretion of antiviral proteins by pig conceptuses in vitro.
\end{abstract}

Keywords: pig; pregnancy; conceptus; interferon; endometrium; proteolysis

\section{Introduction}

Proteins secreted by elongating conceptuses of sheep (ovine trophoblast protein-1, oTP-1) and cattle (bovine trophoblast protein-1, bTP-1) are involved in inhibition of luteolysis and establishment of pregnancy (Godkin et al., 1984a; Knickerbocker et al., 1986; Helmer et al., 1988; Vallet et al., 1988). These proteins have high amino acid sequence homology with alpha II interferons (Imakawa et al., 1987, 1987; Stewart et al., 1987; Charpigny et al., 1988) and oTP-1 has potent antiviral activity (Pontzer et al., 1988). Elongating pig conceptuses also secrete a group of low molecular weight acidic proteins (Godkin et al., 1982). These proteins have been reported to be secreted as early as Day 11 of pregnancy, possess antiviral activity in vitro and cross-react with antiserum to human $\alpha$-interferon (Cross \& Roberts, 1988). In contrast to the antiluteolytic effects of oTP-1 and bTP-1, pig conceptus secretory proteins do not inhibit luteolysis when infused into the uterine lumen of cyclic gilts (Harney \& Bazer, 1989). Rather, they stimulate endometrial

*Reprint requests to Dr Fuller W. Bazer. 
secretion of PGF-2 $\alpha$ and PGE-2 in vivo (Harney \& Bazer, 1989) and in vitro (Dubois \& Bazer, 1988). Oestrogens from pig conceptuses appear to be responsible for establishment of pregnancy in pigs (Bazer et al., 1982).

Secretion of several proteins by the sheep endometrium is stimulated by addition of oTP-1 to culture medium (Godkin et al., 1984b; Vallet et al., 1987; Ashworth \& Bazer, 1989). Conversely, oTP-1 secretion by Day-16 conceptuses is stimulated by co-culture with endometrium from ewes on Day 16 of pregnancy (Ashworth \& Bazer, 1989). Secretory products of pig endometrium also stimulate protein secretion by pig blastocysts (Rice et al., 1981). This study determined the influence of the endometrium, inhibition of proteolysis and freezing on antiviral activity of proteins secreted by pig conceptuses in vitro.

\section{Materials and Methods}

Animals. Sexually mature crossbred (Duroc $\times$ Yorkshire $\times$ Hampshire) gilts were observed daily at $07: 30 \mathrm{~h}$ for oestrous behaviour in the presence of an intact boar. Gilts assigned to the pregnant status were mated when detected in oestrus (Day 0 ) and at 10 and $24 \mathrm{~h}$ after onset of oestrus. All gilts were laparotomized while under general anaesthesia induced with I $g$ thiamylal sodium (i.v.) and maintained with 3-5\% halothane, and the reproductive tract removed.

Experiment 1. Four pregnant gilts were hysterectomized on Day 15. Each uterine horn was flushed with $20 \mathrm{ml}$ sterile $0.9 \%(\mathrm{w} / \mathrm{v}) \mathrm{NaCl}$ to collect conceptuses and confirm pregnancy. Endometrium was dissected from the underlying myometrium and placed in modified Eagle's Minimum Essential Medium (MEM) as described by Godkin et al. (1982). Conceptus tissue ( 0 or $200 \mathrm{mg}$ ) was cultured in a $2 \times 3$ factorial arrangement in the presence of medium only, $200 \mathrm{mg}$ endometrium or $75 \mu \mathrm{g}$ uterine flush proteins collected from a Day 14 cyclic gilt as described by Bazer et al. (1978).

The uterine flush proteins were prepared by concentrating $10 \mathrm{ml}$ of uterine flushing to approximately $3 \mathrm{ml}$ with an Amicon Centriprep device (W. R. Grace \& Co., Danvers, MA, USA) by centrifugation for $40 \mathrm{~min}$ at $4^{\circ} \mathrm{C}$ and $4000 \mathrm{~g}$. The concentrated proteins were then centrifuged for $4 \mathrm{~min}$ at $4^{\circ} \mathrm{C}$ and $13000 \mathrm{~g}$ to remove particulate matter. Protein concentration was determined by the method of Lowry et al. (1951) to be $5 \mathrm{mg} / \mathrm{ml}$.

All combinations of conceptus, endometrium and uterine flush proteins were cultured for $30 \mathrm{~h}$ in $15 \mathrm{ml} \mathrm{MEM}$ (Godkin et al., 1982); medium was then removed, centrifuged to remove cell debris and the supernatant stored at $-20^{\circ} \mathrm{C}$ until assayed for antiviral activity.

Experiment 2. Six pregnant gilts were hysterectomized on Days 10 and 12 (3 gilts/day). The reproductive tracts were removed and endometrium was dissected from the underlying myometrium. Endometrium (200 mg) was cultured in $15 \mathrm{ml}$ MEM and, after $30 \mathrm{~h}$, medium was removed, centrifuged to remove cell debris, and the supernatant stored at $-20^{\circ} \mathrm{C}$ until thawed for use as conceptus culture medium.

Conceptuses were collected from 1 pregnant gilt on Day 15 by flushing the uterine horns with $20 \mathrm{ml}$ sterile MEM. Conceptus tissue $(100 \mathrm{mg})$ was cultured for $30 \mathrm{~h}$ in $7.5 \mathrm{ml}$ of medium conditioned by culture of endometrium from Days 10 and 12 of pregnancy. Conceptus culture medium was centrifuged to remove cell debris, and the supernatant stored at $-20^{\circ} \mathrm{C}$.

Experiment 3. Six pregnant gilts were hysterectomized on Days 12 and 14 ( 3 gilts/day). Each uterine horn was flushed with $20 \mathrm{ml}$ sterile MEM and conceptus tissue cultured $(33.3 \mathrm{mg} / \mathrm{ml})$ in the presence of $0,0 \cdot 01,0 \cdot 1$ and $1 \cdot 0$ trypsin inhibitory units/ml of aprotinin (Sigma Chemical Co., St Louis, MO, USA). After $30 \mathrm{~h}$, culture medium was removed, centrifuged at $1800 \mathrm{~g}$ and $4^{\circ} \mathrm{C}$ for $10 \mathrm{~min}$ and the supernatant recovered. An aliquant of the supernatant was removed and frozen at $-20^{\circ} \mathrm{C}$ for approximately $1.5 \mathrm{~h}$ before thawing at room temperature. The remaining culture medium was stored at $4^{\circ} \mathrm{C}$ for approximately $1.5 \mathrm{~h}$ before warming to room temperature. The antiviral activity in all samples of culture medium were quantified within $2 \mathrm{~h}$ of removal from culture.

Antiviral activity. Samples were analysed for antiviral activity using a cytopathic effect assay (Familletti et al., 1981; Pontzer et al., 1988). Briefly, dilutions of the samples were incubated with Madin-Darby bovine kidney (MDBK) cells for $22-24 \mathrm{~h}$ at $37^{\circ} \mathrm{C}$. Following incubation, inhibition of viral replication was determined using a vesicular stomatitis virus challenge. One antiviral unit inhibited $50 \%$ destruction of the MDBK cell monolayer. Sensitivity of the assay was $<3$ antiviral units/ml.

Statistical analysis. Data were subjected to analysis of variance (ANOVA) using the General Linear Models (GLM) procedure of the Statistical Analysis System (SAS, 1982). For Exp. 1, data were analysed by two-way ANOVA for $2 \times 3$ factorial arrangement of treatments. For Exp. 2, data were analysed by two-way ANOVA for $2 \times 2$ factorial arrangement of treatments with gilts nested within day of pregnancy. For Exp. 3, data were transformed to $\log _{10}$ and analysed by three-way ANOVA for $2 \times 2 \times 4$ factorial arrangement of treatments with gilts nested within day of pregnancy. Tests of hypotheses were performed using appropriate error terms according to the mean-squares expected (Snedecor \& Cochran, 1980). 


\section{Results}

\section{Experiment 1}

Culture medium of conceptuses from one gilt did not possess antiviral activity; therefore, data from all treatment combinations for that gilt were excluded from the analysis. Significant antiviral activity was present only in culture medium containing conceptus tissue $(P<0.05$, Table 1$)$. Conceptuses cultured with Day-15 pregnant endometrium (-54\%) or Day-14 cyclic uterine flush proteins $(-40 \%)$ had reduced $(P<0.05)$ secretion of antiviral proteins into medium. However, the interaction of conceptus tissue with uterine protein $(P<0.06)$ indicated that inhibitory effects of endometrium and uterine flush proteins occurred primarily in cultures containing $200 \mathrm{mg}$ conceptus tissue.

Table 1. The influence of co-culture with endometrium or uterine flush proteins on secretion of antiviral proteins (units/ml) by Day-15 pig conceptuses (Exp. 1)

\begin{tabular}{lcc}
\hline & \multicolumn{2}{c}{ Conceptus tissue $(\mathrm{mg})$} \\
\cline { 2 - 3 } $\begin{array}{l}\text { Co-culture } \\
\text { treatment }\end{array}$ & 0 & 200 \\
\hline Medium only & $<3$ & 1667 \\
Endometrium $(200 \mathrm{mg})$ & $<3$ & 767 \\
$\begin{array}{l}\text { Uterine flushing } \\
\text { proteins }(75 \mu \mathrm{g})\end{array}$ & $<3$ & 1000 \\
\hline
\end{tabular}

$0 \mathrm{mg} v s 200 \mathrm{mg}$ conceptus tissue, $P<0.05$.

Medium $v s$ endometrium + uterine flush proteins, $P<0.05$.

Conceptus $\times$ co-culture treatment interaction, $P<0.06$.

Standard error of least-square means $=132 \cdot 6$.

\section{Experiment 2}

No antiviral activity was detected in endometrium-conditioned culture medium, but was present in that medium after culture of conceptuses $(P<0.05$, Table 2$)$. Secretion of antiviral proteins by conceptus tissue was not influenced differently $(P>0 \cdot 10)$ by culture medium conditioned by endometrium collected on Day 10 compared to Day 12 of pregnancy. However, antiviral activity from conceptus tissue was inhibited completely when cultured in medium conditioned by endometrium from 1 gilt on Day 12 of pregnancy.

\section{Experiment 3}

Conceptuses collected from gilts on Day 12 of pregnancy secreted less $(P<0.01)$ antiviral activity in vitro than those collected on Day 14 (Table 3). For medium assayed unfrozen within $2 \mathrm{~h}$ after culture, antiviral activity was detected for only 1 of 3 gilts on Day 12, but all 3 gilts on Day 14 . Addition of aprotinin to culture medium of conceptuses increased $(P<0.07)$ antiviral activity secreted and orthogonal contrasts detected a quadratic $(P<0.05)$ effect. Addition of 0.01 and $0 \cdot 1$ units $/ \mathrm{ml}$ aprotinin to conceptus cultures increased antiviral activity by 53 and $60 \%$, respectively, while $1.0 \mathrm{unit} / \mathrm{ml}$ increased antiviral activity by only $21 \%$. Aprotinin itself did not possess antiviral activity nor did it enhance antiviral activity when added to medium collected after culture of conceptuses (data not shown). Effects of aprotinin on antiviral activity in medium from Day-12 
Table 2. Influence of medium conditioned by culture of endometrium from pigs at Days 10 and 12 of pregnancy on antiviral proteins (units/ml) secreted by Day-15 conceptus tissue (Exp. 2)

\begin{tabular}{lcccc}
\hline & \multicolumn{3}{c}{ Conceptus tissue (mg) } \\
\cline { 2 - 3 } $\begin{array}{l}\text { Conditioned } \\
\text { culture medium }\end{array}$ & $0 \mathrm{mg}$ & & \multicolumn{2}{c}{$200 \mathrm{mg}$} \\
\cline { 2 - 3 } \cline { 5 - 6 } $\begin{array}{l}\text { Day 10 endometrium } \\
\text { Day 12 endometrium }\end{array}$ & $<3$ & & 450 & $300-750$ \\
\hline
\end{tabular}

$0 \mathrm{mg}$ vs $200 \mathrm{mg}$ conceptus tissue, $P<0.05$.

Day 10 vs Day 12 endometrium did not differ, $P>0 \cdot 10$.

Standard error of least-squares means $=120 \cdot 2$.

and Day-14 conceptus cultures were not different (aprotinin $\times$ day interaction, $P>0 \cdot 10$ ). Freezing and thawing samples of medium from conceptus cultures did not alter $(P>0 \cdot 10)$ antiviral activity detected.

Table 3. The influence of aprotinin and freezing on antiviral proteins (units/ml) secreted in vitro by Day-12 and Day-14 conceptuses (Exp. 3)

\begin{tabular}{llrrrr}
\hline & & \multicolumn{4}{c}{ Aprotinin conc. (units/ml) } \\
\cline { 3 - 6 } $\begin{array}{l}\text { Day of } \\
\text { pregnancy }\end{array}$ & $\begin{array}{l}\text { Condition } \\
\text { of medium }\end{array}$ & 0 & 0.01 & $0 \cdot 1$ & $1 \cdot 0$ \\
\hline 12 & Unfrozen & 3 & 8 & 7 & 7 \\
12 & Frozen & 3 & 7 & 5 & 5 \\
14 & Unfrozen & 2600 & 4100 & 4150 & 2650 \\
14 & Frozen & 2100 & 3133 & 3367 & 2883 \\
\hline Day 12 vs Day $14, P<0.01$. & & & & \\
Aprotinin concentration, & $P<0.07$ & (quadratic & increase, \\
$P<0.05$ ). & & & & \\
Means presented are values for untransformed data and \\
s.e.m = 202. For statistical analysis, data were transformed \\
to $\log _{10}$.
\end{tabular}

\section{Discussion}

The results of the present study indicate that secretory products of pig endometrium can affect secretion of proteins by conceptuses in vitro and agree with the results of Ashworth \& Bazer (1989) for sheep and Rice et al. (1981) for pigs. However, the presence of Day-15 pregnant endometrium or Day-14 cyclic uterine flush proteins decreased secretion of antiviral proteins by Day-15 pig conceptuses in vitro. The secretion of oTP-1 by Day-16 sheep conceptuses was enhanced when they were co-cultured with endometrium from Day-16 pregnant ewes (Ashworth \& Bazer, 1989). Similarly, Rice et al. (1981) reported that endometrial proteins increased protein synthesis by pig blastocysts. The reasons for these apparent discrepancies are not clear, but differential regulation of individual conceptus secretory proteins by the endometrium, as well as variation among species, may occur. The conceptus can stimulate synthesis of some endometrial secretory proteins while inhibiting synthesis of others in sheep (Vallet et al., 1987; Ashworth \& Bazer, 1989). The same may be true for influences of pig endometrium on pig conceptuses. 
One mechanism for regulating secretion of antiviral protein(s) by conceptuses may include effects of retinoic acid and retinol binding proteins (RBP). Retinoids have been reported to block interferon synthesis in vitro (Blalock \& Gifford, 1976, 1977) and pig conceptus secretory proteins with antiviral activity have antigenic similarity to human $\alpha$-interferon (Cross \& Roberts, 1988). Secretion of RBP by pig conceptuses in culture is detectable by Day 12 of pregnancy and increases markedly through Day 15 (Harney \& Mirando, 1989). This pattern of RBP secretion is similar to that for secretion of antiviral proteins by pig conceptuses (Mirando et al., 1990). Secretion of another RBP by pig endometrium is influenced by progesterone (Adams et al., 1981). One may speculate that the potentially inhibitory influence of retinoids on secretion of conceptus interferons may be removed by binding of retinoids by RBP. Alternatively, the amount of antiviral activity present may be reduced through enzymic degradation by endometrial proteins secreted.

Antiviral activity in culture medium of conceptuses and uterine flushings from pregnant gilts increased between Days 10 and 15 (Mirando et al., 1990), suggesting that elongated conceptuses have a greater capacity to secrete antiviral proteins and/or endometrium from earlier in pregnancy is more inhibitory to secretion of proteins with antiviral activity. Therefore, it was of interest to examine the relative influence of endometrium obtained at onset of secretion of antiviral protein(s) (i.e. Days 10-12). However, antiviral acivity from Day-15 conceptuses was not affected differently by endometrium collected on Days 10 and 12 of pregnancy in this study. Endometrial conditioned culture medium representing 1 gilt on Day 12 of pregnancy completely inhibited secretion of antiviral proteins(s) by Day-15 conceptus tissue, but the reason for this is not known. This result supports the concept that secretory products of the endometrium regulate secretion and/or degradation of antiviral proteins from pig conceptuses.

Antiviral activity of conceptus culture medium was not reduced by 1 cycle of freezing and thawing in the present study and loss of antiviral activity of pig conceptus culture medium after repeated freezing and thawing was not detected (M. A. Mirando \& F. W. Bazer, unpublished observations). Pig interferon- $\alpha$ was reported to lose activity during storage at $-20^{\circ} \mathrm{C}$ (Piasecki, 1988); however, we have not detected significant loss of antiviral activity from conceptus culture medium during storage at $-20^{\circ} \mathrm{C}$ for 5-7 months (M. A. Mirando, J. P. Harney \& F. W. Bazer, unpublished observations).

Antiviral activity in cultures of conceptuses from Days 12 and 14 of pregnancy was increased by addition of aprotinin to the culture medium. This effect was not due to aprotinin having antiviral activity or enhancing antiviral activity in conceptus culture medium. Rather, aprotinin apparently increased antiviral activity in conceptus culture medium by inhibiting proteolytic destruction of the protein(s) possessing antiviral activity. Pre-attachment pig conceptuses secrete plasminogen activator (Mullins et al., 1980; Fazleabas et al., 1983, 1985) and may produce other proteases as well. This could account for reduced antiviral activity when aprotinin was omitted from conceptus culture medium in the present study. The uterine endometrium also secretes at least one protease inhibitor (Mullins et al., 1980; Fazleabas et al., 1983, 1985). Consequently, removal of conceptuses from the uterine environment may result in more rapid degradation of antiviral proteins in vitro which could explain the apparently lower antiviral activity in conceptus culture medium compared to uterine flushings (Mirando et al., 1990). Secretion of protease inhibitors by endometrium may provide a system for regulation of antiviral proteins secreted by developing pig conceptuses. However, secretory products of the endometrium also decreased antiviral activity in conceptus culture medium. Inhibitory, as well as stimulatory influences of the endometrium on secretion of proteins by pig conceptuses must, therefore, be considered.

This manuscript is published as University of Florida, Agricultural Experiment Station Journal Series No. 9900. This research was supported by U.S.D.A. Grant 86-CRCR-1-2106. We thank Ms Glenda Walton for assistance in preparation of this manuscript. 


\section{References}

Adams, K.L., Bazer, F.W. \& Roberts, R.M. (1981) Progesterone-induced secretion of a retinol-binding protein in the pig uterus. J. Reprod. Fert. 62, 39-47.

Ashworth, C.J. \& Bazer, F.W. (1989) Interrelationships of proteins secreted by the ovine conceptus and endometrium during the periattachment period. Anim. Reprod. Sci. (in press).

Bazer, F.W., Roberts, R.M. \& Sharp, D.C. (1978) Collection and analysis of female genital tract secretions. In Methods in Mammalian Reproduction, pp. 503-557. Ed. J. C. Daniels. Academic Press, New York.

Bazer, F.W., Geisert, R.D., Thatcher, W.W. \& Roberts, R.M. (1982) The establishment and maintenance of pregnancy. In Control of Pig Reproduction, pp. 227 252. Eds D. J. A. Cole \& G. R. Foxcroft. Butterworth Co., London.

Blalock, J.E. \& Gifford, G.E. (1976) Suppression of interferon production by vitamin A. J. gen. Virol. 32 , 143-147.

Blalock, J.E. \& Gifford, G.F. (1977) Retinoic acid (vitamin A acid)-induced transcriptional control of interferon production. Proc. natn Acad. Sci., USA 75 , 5382-5386.

Charpigny, G., Reinaud, P., Heut, J.C., Guillomot, M., Charlier, M., Pernallet, J.C. \& Martal, J. (1988) High homology between trophoblastic protein (trophoblastin) isolated from ovine embryo and $\alpha$-interferons. Fed Eur. Biochem. Socs 228, 12-16.

Cross, J.C. \& Roberts, R.M. (1988) An interferon produced by elongating porcine embryos. Biol. Reprod. 38 (Suppl. 1), 99, abstr.

Dubois, D.H. \& Bazer, F.W. (1988) Effect of porcine conceptus secretory proteins on endometrial secretion of prostaglandins in vitro. J. Anim. Sci. 66 (Suppl. 1), 404, abstr.

Familletti, P.C., Rubinstein, S. \& Pestka, S. (1981) A convenient and rapid cy topathic effect inhibition assay for interferon. Methods Enzymol. 78, 387-394.

Fazleabas, A.T., Geisert, R.D., Bazer, F.W. \& Roberts, R.M. (1983) Relationships between release of plasminogen activator and estrogen by blastocysts and secretion of plasmin inhibitor by uterine endometrium in the pregnant pig. Biol. Reprod. 29, 225-238.

Fazleabas, A.T., Bazer, F.W., Hansen, P.J., Geisert, R.D. \& Roberts, R.M. (1985) Differential patterns of secretory protein localization within the pig uterine endometrium. Endocrinology 116, 240-245.

Godkin, J.D., Bazer, F.W., Lewis, G.S., Geisert, R.D. \& Roberts, R.M. (1982) Synthesis and release of polypeptides by pig conceptuses during the period of blastocyst elongation and attachment. Biol. Reprod. 27, 977-987.

Godkin, J.D., Bazer, F.W., Thatcher, W.W. \& Roberts, R.M. (1984a) Proteins released by cultured Day 15-16 conceptuses prolong luteal maintenance when introduced into the uterine lumen of cyclic ewes. $J$. Reprod. Fert. 71, 57-64.

Godkin, J.D., Bazer, F.W. \& Roberts, R.M. (1984b) Ovine trophoblast protein 1 , an early secreted blastocyst protein, binds specifically to uterine endometrium and affects protein synthesis. Endocrinology 114, 120-130.
Harney, J.P. \& Bazer, F.W. (1989) Effect of porcine conceptus secretory proteins on interestrous interval and uterine secretion of prostaglandins. Biol. Reprod. 41, 277-284.

Harney, J.P. \& Mirando, M.A. (1989) Retinol-binding protein (RBP): a major secretory product of the pig conceptus. Biol. Reprod. 40, (Suppl. 1), 131, abstr.

Helmer, S.D., Hansen, P.J., Thatcher, W.W., Johnson, J.W. \& Bazer, F.W. (1988) Intrauterine infusion of purified bovine trophoblast protein-1 (bTP-1) extends corpus luteim (CL) lifespan in cyclic cattle. $J$. Anim. Sci. 66 (Suppl. 1) 415, abstr.

Imakawa, K., Anthony, R.C., Kazemi, M., Marotti, K.R., Polites, H.G. \& Roberts, R.M. (1987) Interferon-like sequence of ovine trophoblast protein secreted by embryonic trophectoderm. Nature, Lond. 330, 377-379.

Imakawa, K., Hansen, T.R., Malathy, P.-V., Anthony, R.V., Polites, H.G., Marotti, K.R. \& Roberts, R.M. (1989) Molecular cloning of complimentary deoxyribonucleic acids corresponding to bovine trophoblast protein-1: a comparison with ovine trophoblast protein- 1 and bovine interferon- $\alpha_{11}$. Molec. Endocr. 3, 127-139.

Knickerbocker, J.J., Thatcher, W.W., Bazer, F.W., Drost, M., Barron, D.H., Fincher, K.B. \& Roberts, R.M. (1986) Proteins secreted by Day-16 to -18 bovine conceptuses extend corpus luteum function in cows. J. Reprod. Fert. 77, 381-391.

Lowry, O.H., Rosebrough, N.J., Farr, A.L. \& Randall, R.J. (1951) Protein measurements with folin phenol reagent. J. biol. Chem. 193, 265-275.

Mirando, M.A., Harney, J.P., Beers, S., Pontzer, C.H., Torres, B.A., Johnson, H.M. \& Bazer, F.W. (1990) Onset of secretion of proteins with antiviral activity by pig porcine conceptuses. $J$. Reprod. Fert. 88, 197-203.

Mullins, D.E., Bazer, F.W. \& Roberts, R.M. (1980) Secretion of a progesterone-induced inhibitor of plasminogen activator by the porcine uterus. Cell $\mathbf{2 0}$, $865-872$.

Piasecki, E. (1988) Properties of natural porcine interferons. J. Interferon Res. 8, 61-73.

Pontzer, C.H., Torres, B.A., Vallet, J.L., Bazer, F.W. \& Johnson, H.M. (1988) Antiviral activity of the pregnancy recognition hormone ovine trophoblast protein-1. Biochem. Biophys. Res. Commun. 152, 801-807.

Rice, C., Ackland, N. \& Heap, R.B. (198I) Blastocystendometrial interactions and protein synthesis during pre-implantation development in the pig studied in vitro. Placenta 2, 129-142.

SAS Institute, Inc. (1982) SAS User's Guide: Statistics, 1982 Edition. SAS Institute, Inc., Cary, North Carolina.

Snedecor, G.W. \& Cochran, W.G. (1980) Statistical Methods. Iowa State University Press, Ames, Iowa.

Stewart, H.J., McCann, S.H.E., Barker, P.J., Lee, K.E., Lamming, G.E. \& Flint, A.P.F. (1987) Interferon sequence homology and receptor binding activity of ovine trophoblast antiluteolytic protein. J. Endocr. 115, R13-RI5. 
Vallet, J.L., Bazer, F.W. \& Roberts, R.M. (1987) The effect of ovine trophoblast protein-one on endometrial protein secretion and cyclic nucleotides. Biol. Reprod. 37, 1307-1316.

Vallet, J.L., Bazer, F.W., Fliss, M.F.V. \& Thatcher, W.W. (1988) Effect of ovine conceptus secretory proteins and purified ovine trophoblast protein-1 on interoestrous interval and plasma concentrations of prostaglandins F-2 $\alpha$ and $E$ and 13,14-dihydro-15ketoprostaglandin $\mathrm{F}-2 \alpha$ in cyclic ewes. $J$. Reprod. Fert. 84, 493-504.

Received 20 April 1989 